\title{
Corporate Social Responsibility Communication and Company Reputation in Pandemic Era
}

\author{
Adhianty Nurjanah ${ }^{1, a)}$ \\ ${ }^{1}$ Communication Science, Universitas Muhammadiyah Yogyakarta, Indonesia \\ a) author correspondence: adhianty@umy.ac.id \\ DOI: https://doi.org/10.18196/jkm.12336
}

Article Info

Article history:

Received 16 Jul 2021

Revised 30 Sep 2021

Revised 11 Oct 2021

Accepted 14 Oct 2021

\begin{abstract}
Corporate Social Responsibility (CSR) is a way to build a company's positive reputation. In the new media era and during the COVID-19 pandemic, online media has become an effective communication medium for companies to communicate CSR and build a positive reputation among stakeholders. This study examines BRI Peduli CSR communication during the COVID-19 pandemic through online media on the bri.co.id website that can increase BRI's positive reputation. The research method used in this research is descriptive qualitative research with case study method, data collection is done by in-depth interview and literature study. The data analysis technique was carried out by triangulating sources to get accurate results regarding CSR communications during the COVID-19 pandemic. The results show that effective CSR communication between companies and communities that are beneficiaries of CSR programs will greatly determine the program's success. The CSR program is an official communication channel so that all stakeholders get accountable and reliable information. BRI has also applied the principle of digitization to new media but has not yet reached the level of interactivity and audience-generated media. Online media can build a positive image and be reported CSR Program massively during the COVID-19 pandemic.
\end{abstract}

Keywords: COVID-19; CSR Communication; Reputation; Online Media.

\section{ABSTRAK}

Corporate Social Responsibility (CSR) adalah cara untuk membangun reputasi positif perusahaan. Di era media baru dan di masa pandemi COVID-19, media online menjadi media komunikasi yang efektif bagi perusahaan untuk mengkomunikasikan CSR dan membangun reputasi positif di antara para pemangku kepentingan. Penelitian ini mengkaji komunikasi CSR BRI Peduli di masa pandemi COVID-19 melalui media online di website bri.co.id yang dapat meningkatkan reputasi positif BRI. Metode penelitian yang digunakan pada penelitian ini yakni menggunakan jenis penelitian deskriptif kualitatif dengan metode studi kasus, pengumpulan data dilakukan dengan in-depth interview dan studi pustaka. Teknik analisis data dilakukan dengan triangulasi sumber untuk mendapatkan hasil yang akurat mengenai komunikasi CSR pada saat pandemic COVID-19. Hasil penelitian menunjukkan bahwa komunikasi CSR yang efektif antara perusahaan dengan masyarakat penerima program CSR akan sangat menentukan keberhasilan program. Program CSR merupakan saluran komunikasi resmi agar seluruh pemangku kepentingan mendapatkan informasi yang akuntabel dan terpercaya. BRI juga telah menerapkan prinsip digitalisasi pada media baru namun belum mencapai tingkat interaktivitas dan audiencegenerated media. Penggunaan media online dapat membangun citra positif dan diberitakan secara masif Program CSR selama pandemi COVID-19.

Kata Kunci: COVID-19; Komunikasi CSR; Reputasi; Media Online. 


\section{INTRODUCTION}

Corporate social responsibility (CSR) is a form of responsibility and an obligation that a company must obey. CSR is based on the company's need to interact with its environmental community to adapt and gain social benefits in the form of trust. The company realizes that it should not only pursue profit but also serve the wishes of stakeholders. The company also realizes that if stakeholders lose trust in the company, the company's profits will also disappear. Therefore, the company's survival cannot be separated from its external environment, both natural and social (Hereyah \& Ardiansyah, 2019).

Morsing (2006) stated that CSR communication is designed and distributed by companies whose activities aim to obtain a positive reputation from consumers built through CSR programs (Rusdianto, 2013). The benefits of CSR communication are being a liaison between the company and stakeholders and maintaining company transparency and accountability. Good CSR communication must be trustworthy, informative, educational, and avoid excessive emotions (Rusdianto, 2013). A company that runs CSR programs consistently will create a sense of satisfaction from the consumers, obtain a positive response, and strengthen the relationship between the company and stakeholders. Along with the company's enormous contribution to social responsibility (CSR) programs, it will boost its reputation in the eyes of consumers and the public.

During the COVID-19 pandemic, the company's CSR program has played an essential role in reducing the impact of the pandemic, spreading in Indonesia since March 2020 (Ramli, 2020). Not only the health sector, but the pandemic has also impacted the social and economic sectors. Therefore, the role of companies in reducing the impact of the COVID-19 pandemic can be carried out, with a CSR approach, for instance. Such a way has been performed by Bank Rakyat Indonesia (BRI), which has committed and implemented CSR through the BRI Peduli program as a form of non-natural disaster management efforts for COVID-19.

BRI's CSR program during the COVID-19 pandemic has managed to achieve the TOP CSR Awards category (2021), and the existence of BRI Peduli was recognized nationally and received international awards. BRI's achievements in CSR include receiving an award from Asia Money as the Best Bank for CSR in three consecutive years, 2018, 2019, and 2020 (CNBC Indonesia, 2020). The achievements obtained by BRI were directly proportional to what the public conveyed that the reputation they remembered about the bank's reputation was excellent.

"We really appreciate and are grateful for the assistance from BRI's CSR program because, through this program, we can continue to do activities and production." (Mansyur, a beneficiary of the BRI Peduli CSR program, Boyolali, Central Java, interview on 24 April 2021)

According to Feldman and Vasquez-Parraga (Feldman \& Vasquez-Parraga, 2013), companies have several reasons to carry out CSR activities. First, CSR actions affect consumer reactions to companies and products. Second, information on specific company strategies to retain customers can be obtained through CSR activities. Third, consumers can evaluate companies' CSR activities related to corporate responsibility in economics, law, and ethics. Fourth, communication about CSR activities reveals companies' awareness of CSR, resulting in a positive attitude of consumers to buy products from companies carrying out CSR activities (Husnaini, Sasanti, \& Cahyaningtyas, 2018).

Melo and Galan asserted that a company's competitive advantage could be strengthened through CSR activities (Melo \& Galan, 2011). In addition, Park, Lee, \& Kim suggested that the ethical practice of CSR can create and encourage customer confidence that the company adheres to high ethical standards and cares about the welfare of society (Park, Lee, \& Kim, 2014b). This, in turn, has a positive impact on consumers' assessment of the company's reputation. CSR can build close relationships and communication with the community (Binachi \& Bruno, 2019).

Research conducted by Eienegger \& Schranz with the title of Reputation Management and Corporate Social Responsibility explains that loss of reputation and corporate image is a factor that encourages companies to carry out CSR. In addition, research by Eisenegger \& Schranz conveys that the relationship between CSR communication and media reputation plays a key role in strengthening reputation to the public (Eisenegger \& Schranz, 2011)). The importance of CSR in reputation was also explained by Petkeviciene, who emphasized that CSR is an important element in building and maintaining a company's reputation and influencing strategic resource factors to become a company's competitive advantage. The results of his research show that CSR and reputation greatly affect the conditions of intense competition and provide choices for stakeholders (Šontaitè-Petkevičiené, 2015). The use of social media that plays a role in communicating CSR is also discussed in Ali et al. (2016). 
The study was titled Using Social Media for CSR Communication and Engaging Stakeholders and explained the tremendous potential of social media for CSR communication in this modern era (Ali et al., 2015). The research results stated that communication through social media would be more transparent and helpful in shaping the behavior of more profitable stakeholders (Ali et al., 2015). Based on the literature presented in previous studies, the research to be carried out will fill the space for language limitations that have been carried out by previous research.

Based on some previous literature, this study identified a gap that will lead to new findings on building a good reputation through online CSR media communication. If the previous research only discussed CSR and reputation barriers and social media with CSR, this research will explain in a complex way how online media, especially on the bri.co.id website, functions as a CSR communication medium to form a good reputation. Therefore, this study will discuss related Communicating the CSR programs implemented is crucial to let the public know the performance and be sympathetic to BRI. This study aims to analyze how to communicate CSR to build a good reputation in BRI.

CSR has developed and is one of the topics inseparable from the business world as it is a company's moral obligation for internal and external. The company's moral obligation includes environmental protection, relations with local communities, the work environment, and donations or assistance. As stated by John Elkington, it follows the guidelines of the three pillars of CSR, known as the 3P: profit, people, and planet. The slogan means seeking profit, providing the welfare of people, and ensuring the sustainability of the planet's life (Elkington, 1998). According to the concept, CSR is packaged into three principal components: Profit, Planet, and People (3P). This concept provides an understanding that a company is said to be good if the company is not only looking for profit (profit) but also have a concern for environmental sustainability (planet) and welfare of society (people). Company management responsibilities have initially been only to stockholders (owners/shareholders) shifted to stakeholders (owners, employees, government, and the wider community).

The company is committed to operating sustainability based on economic, social, and environmental principles while balancing various stakeholders' interests. The International Organization for Standardization, an international certification body, developed the international standard ISO 26000 on Guidance on Social Responsibility and provided a definition of CSR. According to ISO 26000, CSR is "The responsibility of an organization for the impacts of its decisions and activities on society and the environment which is manifested in the form of transparent and ethical behavior that is in line with sustainable development and the welfare of society; taking into account the expectations of stakeholders, in line with established laws and international norms of behavior; and integrated with the organization as a whole" (ISO 26000, 2010).

Crowther David (2008), in the book Corporate Social Responsibility (Hadi, 2011), divided the principles of CSR into three: (1) Sustainability is related to activities (actions) carried out by the company by considering the sustainability of resources in the future. It is meant in the use of current resources while considering the capabilities of future generations. (2) Accountability is the business of a public company and is responsible for the activities carried out. It is required when the company's activities affect and are influenced by the external environment. It can be used as a medium for companies to build an image and network for stakeholders. (3) Transparency is essential for external parties, which reduces information asymmetry, misunderstanding, especially information, and accountability for various environmental impacts.

CSR strategies to reduce the negative impact of company operations and increase positive contributions to stakeholders will be in vain if stakeholders do not know and do not get information about the implementation of the company's CSR activities. Communicating CSR activities to stakeholders is an important step in implementing CSR programs. The current business conditions challenge companies to be socially responsible to all stakeholders. Companies need to communicate the company's contribution to social, environmental, and ethical issues as a company's business strategy (Yudarwati in Nurjanah, 2017). One of the effective new media as CSR communication media is the company website. In the new media era, the website is a strategic communication tool for companies, including as a CSR communication medium. Considering the rapid use of the internet among the community, the use of company websites to communicate CSR programs deserves more consideration (Nurjanah, 2017).

A company's reputation is highly dependent on the perception of stakeholders toward the company's CSR. According to Unerman, CSR can influence stakeholder perceptions, thereby maximizing the company's reputation (Unerman, 2008). Husted and Allen explained that CSR 
positively affects the company's reputation (Husted \& Allen, 2007). CSR reporting improves the company's reputation and financial performance because it is one way to attract foreign investors and increase customer satisfaction and employee commitment (Bayoud \& Kavanagh, 2012). Signaling theory underlies voluntary disclosure. Suwardjono stated that management always tries to disclose private information, which according to its considerations, is of great interest to investors and shareholders, especially if the information is good news even though it is unnecessary. CSR reporting is a way for a company to signal stakeholders, hoping that the information will improve the company's reputation (Suwardjono, 2006). CSR program that is not carried out properly will affect a bad reputation and will result in a crisis for a company (Kriyantono, 2019).

Reputation affects organizational legitimacy in two ways. First, reputation affects relationships between organizations. From an institutional perspective, this relationship expands organizational networks that represent an important way for organizations to adapt, especially to normative and cognitive pressures (D'Aveni and Kesner, in Windanaputra, 2018). Second, reputation plays a largely symbolic role. In both ways, reputation provides a signal from the time the company adapts to the environment and from when investors are able to conclude these possible cues. According to Rao, top management is the guardian of reputation, and the ability of top management is expected to maintain reputation and become the basis for measuring company performance (Widanaputra, Widhyadanta, \& Ratnadi, 2018). In addition, the ability to maintain reputation is the basis for measuring company performance and customer loyalty.

Over the past decade, new media has significantly impacted the practice of public relations (PR) as one of the useful tools to achieve PR goals. New media contain elements of integration, interactivity, and the use of digital codes. With this understanding, new media is often used interchangeably with multimedia, interactive media, and digital media (Van Dijk, 2006). Meanwhile, Andreas Kaplan and Michael Haenlein defined new media as a group of Internet-based applications that build on the ideological and technological foundations of Web 2.0 and enable the creation and exchange of user-generated content. Web 2.0 is the primary platform for new media (Wibowo, 2014). Digital media used by Public Relations will help to communicate CSR programs and have a good impact on relationships with stakeholders Du \& Viera, 2012; Colleoni, 2013; Etter, 2013; Dutot, Lacalle Galvez \& Versailles, 2016; Camilleri, 2018a; 2017b in (Troise \& Camilleri, 2021).

Grunig also suggests that the presence of social media has changed the way practitioners think and carry out their practices and assumes that this is a revolutionary force in public relations. Grunig also believes that with social media optimization, public practice relations will be more global, more strategic, more communicative bidirectional and interactive, symmetrical or dialogic, and more responsible socially. It can be underlined that in this new era, social media can be used as one of the media used in strategic public relations in communication with the public (Pienrasmi, 2015). According to Grunig, media can also be used by public relations for some interests, such as that digital media can be used to perform communication programs. These include, among others, program communication with the media, dealing with customers, getting in touch with coworkers, relating to the community, liaising with members of the organization non-profit, donor relations, relationship with alumni, get in touch with the government. That matter is done solely to create relations with the public. Following new media can be used to perform environmental scans. Scanning the environment here has an understanding to detect potential problems and issues that are developing related to the organization (Grunig, 2009).

\section{METHODS}

This research on CSR communication and company reputation in the COVID-19 pandemic belongs to qualitative descriptive research with a case study method. This study focused on discovering how CSR communication could support a good company reputation during the pandemic. The use of the case study method is due to the research context in a pandemic situation and companies using new media as a form to build reputation. So this will be a specific discussion regarding the company's efforts to use social media to convey CSR activities during the COVID-19 pandemic. The data were collected through in-depth interviews with CSR program beneficiaries and literature review based on data or documents produced by companies such as reports obtained from websites and news in online media. According to Miles and Huberman, data analysis is carried out, in which the activities in qualitative data analysis are carried out interactively until the data are saturated (Miles \& Huberman, 1992). The stages of data analysis involve data reduction, data display, and conclusion drawing. The analytical technique used in this study is through triangulation of sources to find accurate and 
appropriate data between the data obtained in the document study and the results of the interview. The validity of the secondary data was analyzed by comparing the results of interviews with the Tumang community who received the CSR program, which is the primary data of research data and compared with documents from the related institutions. This method revealed how BRI carried out CSR communication in implementing the BRI Peduli CSR program.

\section{RESULT AND DISCUSSION}

The COVID-19 pandemic was a disaster that resulted in losses for various sectors, including BRI as a national bank. Nevertheless, the COVID-19 pandemic did not prevent BRI from carrying out social responsibility and business ethics through CSR programs. Corporate CSR should have a great opportunity during COVID-19 to produce the best innovations to contribute meaningfully socially as a form of contribution to sustainable development and establish harmonization between the company and its customers, especially during the COVID-19 pandemic. The CSR practices of the BRI Peduli Program during the COVID-19 pandemic were providing soft loans, procuring aid funds, and the Indonesia Peduli program related to handling natural and non-natural disasters. In implementing the CSR program, communication activities between the company and the beneficiaries of the program are very important. The existence of effective communication between companies and community beneficiaries of CSR programs will greatly determine the success of the program. In this case, the company must create a two-way communication, both within the company and with the community who are the beneficiaries of the CSR program.

The CSR communication function is important, especially in providing correct and transparent information about company integration, social and environmental concerns and interactions with stakeholders. In addition, CSR communication can be used to anticipate stakeholder expectations, articulate CSR policies, and become an official communication channel so that all stakeholders get accountable and reliable information to contribute to advancing the company's image and reputation in the future. According to Morsing (2006), CSR communication strategy consists of two strategies: providing information and the strategy of interacting and process. In this case, the form of a two-way communication process interaction strategy is shown by implementing the BRI Peduli CSR program and providing information. In this case, what BRI does is to communicate the CSR program through the BRI website media.

\section{Analysis Principle BRI's Corporate Social Responsibility Communication}

PT Bank Rakyat Indonesia (Persero) Tbk (BRI) is a state-owned company (BUMN) engaged in banking and one of the largest commercial banks in Indonesia that always puts customer satisfaction first with its slogan "Serving with Sincerity". BRI has developed many CSR programs carried out by BRI Peduli, both in handling the COVID-19 pandemic and other programs needed by the community. The CSR interaction strategy carried out by Bank BRI shows a two-way communication process that the company can carry out and encourages dialogue with stakeholders. This communication is carried out to increase understanding of stakeholder expectations. In implementing CSR programs, the communication process plays a significant role. As a company must create two-way communication internally and externally with the public, who are the program's beneficiaries, every company that implements CSR must understand effective CSR communication to stakeholders. The communication function is important in the implementation of CSR (Hambali, Kawengian, \& Tulung, 2017).

In addition, according to Rusdianto (2013), CSR communication is a company's effort to communicate with each stakeholder regarding the company's commitments, policies, programs, and performance in the economic, environmental and social pillars. Companies can use CSR communication to build a reputation. The company will manage CSR communication carefully as it understands the potential of CSR activities on its reputation. Thus, BRI also manages CSR communication carefully and performs the right CSR strategy to society's responsibility while focusing on running the bank's business and operations. BRI's role in the BRI Peduli program prioritizes its contribution to caring for the community or the environment, such as conveyed by The Vice President of Corporate Secretary of BRI, Aestika Oryza Gunarto, said that BRI also continued to play a role in social responsibility in society. 
"The BRI Peduli program is carried out based on three alignments called 3P: pro-planet, propeople, and pro-profit. These are values that we want to drive into all levels of BRI to the ends of the world's borders." (Aestika Oryza Gunarto, Vice President of Corsec of BRI, interview of CNBC on 2 Maret 2021)

Aestika's explanation demonstrated that BRI had implemented the $3 \mathrm{P}$ or triple bottom line following the Elkington concept that explains if the good company is not only looking for profit (profit), but also have a concern for environmental sustainability (planet) and welfare of society (people) (Elkington,1998). Company management responsibilities which originally applied to stockholders (owners/shareholders), were shifted to stakeholders (owners, employees, government and the wider community). It was carried out through BRI Peduli, following the Regulation of the Minister of SOEs No. 2 of 2017, regulating the improvement of community welfare and environmental conservation. CSR program will change the views of the public, investors and the government. In turn, CSR will encourage companies to show forms of corporate social responsibility that are not limited to composition, quality and safety improvement activities, products, production techniques and processes, and proses use of human resources.

BRI has four principles that must be considered in carrying out a CSR program. Transparencythis principle requires every social responsibility program to be managed openly, allowing all stakeholders to know and understand and have the opportunity to participate in managing a CSR program. Accountability - the principle of accountability requires every party involved in managing a social responsibility program to effectively carry out their duties and authorities to be accounted for from time to time, both to internal and external stakeholders. Responsibility - this principle requires the manager of the social responsibility program to be responsible for every decision. This responsibility must extend to every person in the program management organization or other parties related to the management of the CSR program. Inclusion - this principle stipulates the importance that every social responsibility program carried out by companies can reach and involve stakeholders so that they are not only objects but also the subject or actor of the program. Inclusiveness also means that the social responsibility program implemented is assured of targeting vulnerable and community groups directly affected by the company's operations (BRI, 2020).

The implementation of CSR programs during the COVID-19 pandemic carried out by BRI included Assistance for Operational Support Equipment for the Emergency Hospital Corona Virus Disease 2019 (COVID-19) Handling of Kemayoran Athlete House, Sharing Food through Brilink Agents in the context of controlling the spread of COVID-19, Supporting Equipment Assistance Hospital Health in the context of dealing with COVID-19, and assistance in the procurement of ambulances in various regions. The implementation of CSR carried out by BRI is a form of BRI's social responsibility to look at the surrounding situation on social issues, where the world is now experiencing a tremendous impact due to the COVID-19 pandemic. The CSR program implemented is not only in partnership with the government but also contributes to the health sector and directly to the community through the Brilink Agent. Based on the CSR program implemented by BRI, it has resulted in a good response from stakeholders, who talk to customers and affect the positive reputation of the wider community, government, and related sectors who have benefited from the BRI Cares CSR program. In addition, the CSR efforts carried out will be successful in showing BRI's performance that remains maximal even during the COVID-19 pandemic.

"We really feel that the BRI program is very contributing in handling and helping the community in the era of the COVID-19 pandemic. We as a community feel that the program from BRI is very suitable for what we need, so we have a good relationship with BRI, and in our eyes BRI always has a good image." (Abdiyo, Tumang Community, recipient of BRI's CSR program, interview on 24 April 202)

CSR actions taken by BRI more or less affect consumer reactions to the company and its products. So that from the information received by the beneficiary community, they get satisfaction with BRI so that they become loyal customers of BRI. In addition, the communication process about CSR activities reveals the company's awareness of CSR. BRI does this by conveying it online to generate a positive attitude for consumers to buy products from companies that carry out CSR activities. This is in accordance with what was conveyed by Husnaini., Susanti, and Cahyaningtyas that through CSR you will get other luck that follows the results of CSR implementation (Husnaini, Sasanti, \& Cahyaningtyas, 2018). CSR also has a positive impact on consumers' assessment of the company's reputation. CSR can build close relationships and communication with the community (Binachi \& Bruno, 2019). 


\section{Website as a Media Communication Corporate Social Responsibility Program}

The delivery of information on CSR programs carried out by BRI is carried out by providing the latest issues related to the CSR program plan to stakeholders. The purpose of presenting this information as a consideration for stakeholders is to demonstrate the company's expectations.BRI actively communicated CSR programs and reports on CSR principles to obtain a good reputation through the bri.co.id website. The website has been an effective online communication medium in informing the programs and activities that BRI has produced. The bri.co.id website has a special column to explain the BRI Cares CSR program.

Interestingly, the CSR program carried out by BRI is not just one activity but has seven categories of BRI Cares CSR Program. Seven of these programs include Indonesia Sejahtera (which focuses on social assistance for poverty alleviation), Indonesia Peduli (Aid for natural disasters and non-natural disasters including those caused by epidemics), Indonesia Sehat (Health improvement assistance), Indonesia Lestari (Aid for environmental conservation and nature), Indonesia Cerdas (educational assistance provided in the form of training, educational infrastructure and facilities), Indonesia Takwa (assistance for worship facilities), and Indonesia Pembangunan (assistance for the development of public infrastructure and facilities).

The naming of the BRI Peduli CSR program describes the focal point of BRI's CSR implementation for the benefit of the Indonesian people and in accordance with the company's vision and mission. The program carried out by each category due to observations by researchers shows progress and balanced CSR implementation in carrying out CSR principles and covering various aspects of community needs. Based on this, BRI, through its CSR program, contributes not only to building a good reputation but also having an impact in accordance with the benefits felt by the community so that it will support the loyalty of the community and BRI customers. This is as stated in Lee et. al's research (2017), that empirically CSR activities have a positive and significant effect on company reputation and customer loyalty and brand image (Park et.al ., 2014).

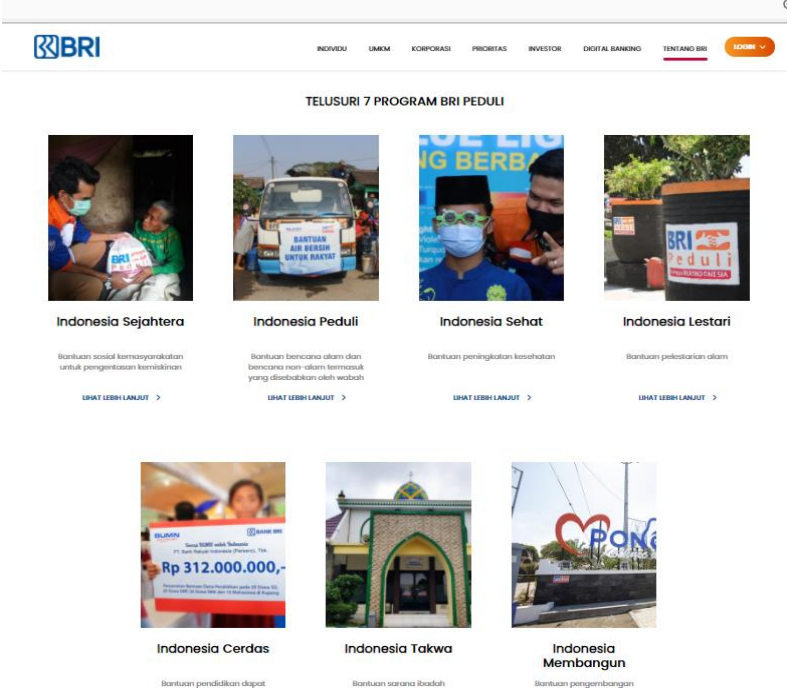

Figure 1. Display of the Bri.Co.Id Website in the CSR Column

The BRI website, which shows CSR programs that care about the community, especially during the pandemic, provides customer participation to believe that BRI is a state-owned bank that pays attention to the social environment. Through the CSR program communication website, BRI can be a means of transparency and accountability. Moreover, the suitability of the program design carried out simultaneously during the COVID-19 pandemic provided enthusiastic community participation with the good reputation of BRI.

On the bri.co.id website, various BRI Peduli programs are displayed included in seven categories of CSR program forms that BRI has implemented. The form of communicating the CSR program that has been implemented is manifested in the form of a written release that explains the purpose and form of the program. However, the BRI Peduli website specifically for communicating CSR programs 
does not have a column for questions, answers, or interactions. However, it requires other social media to interact, namely utilizing social media such as Youtube, Instagram, Facebook, Twitter, Email, and Telephone media. This is in accordance with what was conveyed by Grunig that the public relations can also use media for following interests, such as digital media can be used to perform communication programs. New media can be used to perform environmental scans. Scanning the environment here has the understanding to detect potential problems and issues that developing related to organization (Grunig, 2009)

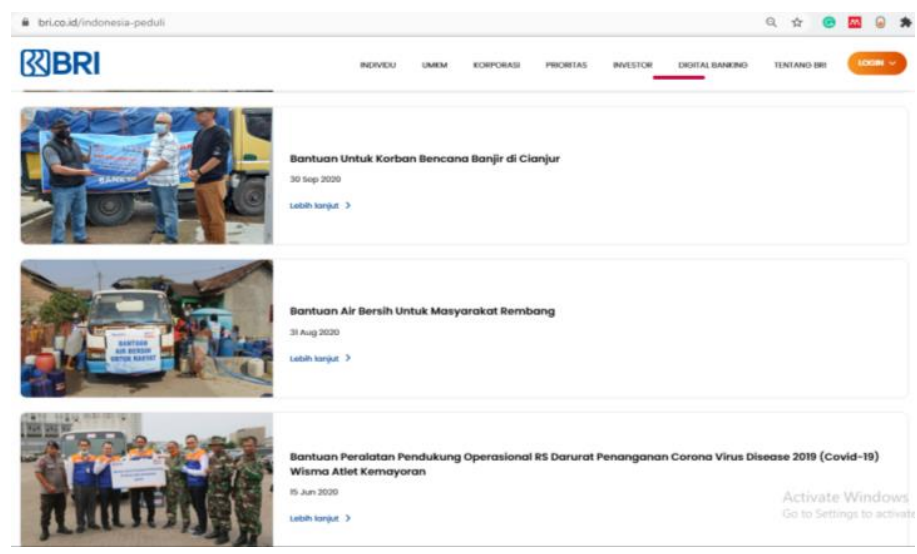

Figure 2. Various BRI Cares Program Activities

According to LaRose and Strubhaar (LaRose \& Strubhaar, 2008), regarding new media, the bri.co.id website has implemented the principles of digitization, allowing relatively easy and fast information to be conveyed to the public widely and quickly. However, the website has not implemented the nature of interactivity, if this interactivity will allow two-way interaction between content providers and content recipients in the media. Thus, the audiences or recipients of content obtain new power to select messages and contribute to the content. Nevertheless, to implement audience-generated media, which is user-centric or focused on users, digital new media currently allows audiences to produce content, such as comments, tweets, blogs, and others.

The step to communicate CSR has implemented the principles of digital PR as the dominant communication tool (Holtz, 2002). Reach - the digital content can reach the public easily considering the internet blends geographical boundaries. Ease of Use - this technology allows digital content to be accessed through many media and available at any time. Speed - information content can be obtained in just minutes, even seconds. Hence, new media are associated with real-time media or provide direct information. Moreover, convergence - is the innovation of new media in PR, encouraging media convergence by content creators.

Media can also be used by public relations for some interests, such as that digital media can be used to perform communication programs. These include, among others, program communication with the media, dealing with customers, getting in touch with coworkers, relating to the community, liaising with members of the organization non-profit, donor relations, relationship with alumni, get in touch with the government. That matter is done solely to create relations with the public. Following new media can be used to perform environmental scans. Scanning the environment here has the understanding to detect potential problems and issues that are developing related to the organization.

Digital media is also used to communicate corporate CSR programs. Companies need to communicate CSR programs and whatever they do to gain legitimacy and a good reputation from their stakeholders. One form of CSR program is communicated through interactive online media (Troise \& Camilleri, 2021). It is proven that the use of online media increases interactivity and good reputation, such as public trust with a positive Word of Mouth strategy. Delivering a credible and strong message by the company will have a positive reputation impact. These results imply that the promotion of CSR communication through interactive can improve the reputation of business firms. Like research on CSR programs of Italian companies (about $76 \%$ of them) communicate about their CSR efforts to stakeholders. In fact, they publish their annual CSR report on the website, and some companies also promote CSR through digital media (Troise \& Camilleri, 2021). 
BRI as a company routinely communicates CSR programs through news releases and inputs to the annual report every year. Thus, communicating CSR will impact a good reputation through online media, such as a website with more complex features to communicate and interact with relevant stakeholders. Based on this, CSR communication carried out through the online media of bri.go.id will undoubtedly build a good corporate reputation because BRI has actively participated in caring for and assisting the community in dealing with COVID-19.

\section{CONCLUSION}

Effective CSR communication between companies and communities who are beneficiaries of CSR programs will greatly determine the program's success. Companies must be able to create two-way communication (two-way communication). The CSR program is an official communication channel so that all stakeholders get accountable and reliable information to contribute to advancing the company's image and reputation. During the COVID-19 pandemic, a company's CSR program rollout has played a vital role in reducing the impact of the COVID-19 pandemic spreading in Indonesia. BRI has committed and implemented CSR through the BRI Peduli program as a form of non-natural disaster management efforts for COVID-19. The BRI's CSR program has implemented four principles: accountability, transparency, responsibility, and inclusion. In carrying out its CSR program, BRI communicated CSR through an online media approach, the bri.go.id website, and has implemented the principles of digitization in new media, but has not yet reached the level of interactivity and audience-generated media. By implementing the principles of digital PR, CSR communication carried out through the bri.go.id website will undoubtedly build an excellent corporate reputation because BRI has actively participated in caring for and assisting the community in dealing with COVID-19.

\section{REFERENCES}

Ali, I., Jiménez-Zarco, A. I., \& Bicho, M. (2015). Using Social Media for CSR Communication and Engaging Stakeholders. Developments in Corporate Governance and Responsibility, 7(1), 165-185. https://doi.org/10.1108/S2043-052320150000007010

Bayoud, N. ., \& Kavanagh, M. (2012). Corporate social responsibility disclosure: evidence from Lybian managers. Global Journal of Business Research, 6(1), 73-83.

Binachi, E., \& Bruno, J. M. (2019). The Impact of Perceived CSR on Corporate Reputation and Purchase Intention. European Journal of Managment and Business Economics, 28(3), 206221.

BRI. (2020, June 15). Bantuan Peralatan Pendukung Operasional RS Darurat Penanganan Corona Virus Disease 2019 (COVID-19) Wisma Atlet Kemayoran - Bank BRI | Melayani Dengan Setulus Hati. Retrieved July 10, 2021, from bri.co.id website: https://bri.co.id/-/bantuanperalatan-pendukung-operasional-rs-darurat-penanganan-corona-virus-disease-2019-COVID19-wisma-atlet-kemayoran

CNBC Indonesia. (2020, October 9). BRI Borong 2 Penghargaan Bergengsi dari Asiamoney. Retrieved July 10, 2021, from https://www.cnbcindonesia.com/ website: https://www.cnbcindonesia.com/market/20201009112751-17-193110/bri-borong-2penghargaan-bergengsi-dari-asiamoney

Eisenegger, M., \& Schranz, M. (2011). Reputation Management and Corporate Social Responsibility. In Ø. Ihlen, J. L. Bartlett, \& S. May (Eds.), The Handbook of Communication and Corporate Social Responsibility (pp. 128-146). New Jersey: John Wiley \& Sons. https://doi.org/10.1002/9781118083246.ch7

Elkington, J. (1998). Cannibals With Forks: The Triple Bottom Line in 21st Century Business. BC: New Society Publishers.

Feldman, P. ., \& Vasquez-Parraga, A. . (2013). Consumer social responses to CSR initiatives versus corporate abilities. Journal of Consumer Marketing, 30(1), 100-111.

Grunig, J. E. (2009). Excellence in Public Relations and Communication Management. New Jersey: Lawrence Erlbaum Associates Publishers.

Hadi, N. (2011). Corporate Social Responsibility. Yogyakarta: Graha Ilmu. 
Hambali, M. M., Kawengian, D., \& Tulung, L. (2017). Strategi Humas Perusahaan Donggi Senoro Liquefied Natural Gas Dalam Membangun Citra Positif Melalui Program Corporate Social Responsibility Di Kecamatan Batui Kabupaten BanggaI. e-journal Acta Diurna, 6(1), 1-21.

Hereyah, Y., \& Ardiansyah, H. (2019). Program Corporate Social Responsibility BRI Peduli dalam Meningkatkan Citra PT Bank Rakyat Indonesia. JOURNAL OF MEDIA AND COMMUNICATION SCIENCE, 1(3), 120-131.

Holtz, S. (2002). Public Relations on The Net 2nd Edition. New York: Amacom.

Husnaini, W., Sasanti, E. E., \& Cahyaningtyas, S. R. (2018). Corporate Social Responsibility (CSR) dan Reputasi Perusahaan. Jurnal Aplikasi Akuntansi, 2(2), 1-9. https://doi.org/10.29303/jaa.v2i2.22

Husted, B. W., \& Allen, D. B. (2007). Strategic Corporate Social Responsibility and Value Creation among Large Firms: Lessons from the Spanish Experience. Long Range Planning, 40(6), 594-610.

ISO 26000. (2010). ISO 26000 International Standard - Lignes directrices relatives à la responsabilité sociétale. Retrieved from www.iso26000.info

Kriyantono, R. (2019). The Implementation of the Regulation of the Minister of Administrative Reform and Bureaucratic Reform No 29/2011 in Crisis Management of Government Public Relations. Jurnal Komunikator, 11(2), 93-106. Retrieved from https://journal.umy.ac.id/index.php/jkm/article/view/6863/4677

LaRose, R., \& Strubhaar, J. (2008). Media Now: Understanding Media, Culture and Technology 5th Edition. Belmont: Thompson Learning.

Melo, T., \& Galan, J. (2011). Effects of Corporate Social Responsibility On Brand Value. Journal Of Brand Management, 18(1), 423-437.

Miles, B. M., \& Huberman, M. (1992). Analisis Data Kualitatif Buku Sumber Tentang Metodemetode Baru. Jakarta: UI Press.

Nurjanah, S. D. (2017). Komunikasi Corporate Social Responsibility Pada Official Website Perusahaan Badan Usaha Milik Negara. Aspikom, 3(2), 311-325.

Park, J., Lee, H., \& Kim, C. (2014a). Corporate Social Responsibilities, Consumer Trust And Corporate Reputation: South Korean Consumers' Perspectives. Journal Of Business Research, 67(3), 295-302. https://doi.org/Doi.Org/10.1016/J.Jbusres.2013.05.016

Park, J., Lee, H., \& Kim, C. (2014b). Corporate Social Responsibilities, Consumer Trust And Corporate Reputation: South Korean Consumers Perspectives. Journal Of Business Research, 67(3), 295-302.

Pienrasmi, H. (2015). Pemanfaatan Social Media Oleh Praktisi Public Relations Di Yogyakarta. Jurnal Komunikasi, 9(2), 199-210. https://doi.org/10.20885/komunikasi.vol9.iss2.art6

Ramli, R. (2020). Enam Bulan Pandemi, Bagaimana Kondisi Perbankan Nasional? Retrieved from Kompas.com website: https://money.kompas.com/read/2020/09/17/153400226/enam-bulanpandemi-bagaimana-kondisi-perbankan-nasional-?page $=$ all

Rusdianto, U. (2013). CSR Communication a Framework for PR Practitioners. Yogyakarta: Graha Ilmu.

Šntaitè-Petkevičienè, M. (2015). CSR Reasons, Practices and Impact to Corporate Reputation. Procedia - Social and Behavioral Sciences, 213, 503-508. https://doi.org/10.1016/j.sbspro.2015.11.441

Suwardjono. (2006). Teori Akuntansi: Perekayasaan Laporan Keuangan, Edisi Ketiga. Yogyakarta: BPFE UGM.

Troise, C., \& Camilleri, M. A. (2021). The Use of Digital Media for Marketing, CSR Communication and Stakeholder Engagement. Strategic Corporate Communication in the Digital Age, (November 2020), 161-174. https://doi.org/10.1108/978-1-80071-264-520211010

Unerman, J. (2008). Strategic Reputation Risk Management And Corporate Social Responsibility Reporting. Accounting, Auditing \& Accountability Journal, 21(1), 362-364.

Van Dijk, J. (2006). The Network Society (2nd ed). London: Sage Publications Inc.

Wibowo, S. E. (2014). Analisis Pemanfaatan Media Digital sebagai Strategi Komunikasi Program CSR PT. L'OREAL Indonesia. In FISIP UI. Jakarta: FISIP UI.

Widanaputra, A. A., Widhyadanta, I. D., \& Ratnadi, N. D. (2018). Reputasi Perusahaan, Reputasi Manajemen Puncak, Dan Pengungkapan Corporate Social Responsibility. Jurnal Ilmiah Akuntansi dan Bisnis, 13(2), 75-84 